\title{
PENGARUH JARAK TANAM PADA SISTEM TANAM JAJAR LEGOWO TERHADAP PRODUKTIVITAS PADI VARIETAS INPARI 32
}

\author{
Ina Martina ${ }^{1}$ dan Asep Pebriandi ${ }^{1}$ \\ ${ }^{1}$ Balai Pengkajian Teknologi Pertanian Kalimantan Timur. Indonesia. \\ E-Mail: inamartina11@yahoo.com
}

\begin{abstract}
ABSTRAK
Pengaruh Jarak Tanam Pada Sistem Tanam Jajar Legowo Terhadap Produktivitas Padi Varietas Inpari 32. Salah satu upaya dalam meningkatkan produktivitas padi yaitu penerapan teknologi budidaya dengan pengaturan populasi tanaman melalui pengaturan jarak tanam dan sistem tanam jajar legowo. Tujuan dari peneltian adalah untuk mengetahui produktivitas varietas Inpari 32 menggunakan sistem jajar legowo 2:1 dengan perlakuan jarak tanam yang berbeda. Pengkajian dilaksanakan pada lahan sawah KP Samboja, Desa Bukit Raya, Kecamatan Samboja Kabupaten Kutai Kartangera Kalimantan Timur pada bulan JuliOktober 2019. Pengkajian terdiri atas 2 perlakuan jarak tanam sistem tanam jajar legowo 2:1, yaitu $20 \mathrm{x} 10 \mathrm{x}$ $40 \mathrm{~cm}$ dan $20 \times 10 \times 50 \mathrm{~cm}$, masing-masing perlakuan diulang 3 kali. Analisis data untuk membandingkan antara 2 perlakuan jarak tanam jajar legowo 2:1 menggunakan uji t berpasangan. Hasil pengkajian menunjukkan perlakuan jarak tanam $(25 \times 12,5 \times 50 \mathrm{~cm})$ pada karekter tinggi tanaman, jumlah anakan produktif, panjang malai, jumlah gabah berisi per malai serta hasil memiliki nilai rerata yang lebih tinggi dan nyata dibandingkan denga perlakuan jarak tanam $(20 \times 10 \times 40 \mathrm{~cm})$.
\end{abstract}

Kata kunci : Inpari 32, Jajar legowo, Jarak tanam, Produktivitas.

\begin{abstract}
The Effect of Spacing in the Legowo Jajar Planting System on Rice Productivity of Inpari 32. One of the efforts in increasing rice productivity is by applying cultivation technology by regulating plant populations through setting plant spacingand jajar legowo planting systems. The purpose of the study was to determine the productivity varieties of Inpari 32 using Jajar Legowo 2:1 system with different spacing plant treatments. The study was conducted in KP Samboja, Bukit Raya Village, Samboja District, Kutai Kartangera Regency, East Kalimantan in July-October 2019. The study consisted of 2 spacing treatments of 2:1 jajar legowo row planting system, was $20 \times 10 \times 40 \mathrm{~cm}$ and $20 \times 10 \times 50 \mathrm{~cm}$, each treatment was repeated 3 times. Analysis of the data to compare between 2 treatments spacing jajar legowo 2:1 using paired t test. The results of the study showed the treatment of plant spacing $(25 \times 12.5 \times 50 \mathrm{~cm})$ on plant height, number of productive tillers, panicle length, number of filled grains per panicle and yields had higher mean values and were significantly different, compared with spacing treatments planting $(20 \times 10 \times 40 \mathrm{~cm})$.
\end{abstract}

Key words : Inpari 32, Jajar Legowo, Plant spacing, Productivity.

\section{PENDAHULUAN}

Padi merupakan komoditas tanaman pangan paling penting dan banyak dibudidayakan di Indonesia karena merupakan bahan pokok sebagai sumber karbohidrat dari sebagian besar penduduk Indonesia. Pertumbuhan jumlah penduduk yang pesat menjadi tantangan dalam upaya meyediakan pangan. Untuk itu perlu upaya untuk

meningkatkan produksi padi.
Peningkatan produksi padi dapat
dilakukan dengan cara tiga pendekatan
yaitu meningkatkan produktivitas
tanaman, menambah luas area panen, dan
menambah intensitas tanam (Hamdani
$\begin{array}{llr}\text { dan Murtiani, 2014). Menurut } \\ \text { (Sembiring, 2008) } & \text { peningkatan } \\ \text { produktivitas merupakan cara yang } \\ \text { dianggap } & \text { berhasil } & \text { dalam }\end{array}$


menyumbangkan peningkatan poduksi padi, dibandingkan dengan peningkatan luas panen. Salah satuupaya dalam meningkatkan produktivitas padi adalah melalui penerapan teknologi budidaya yaitu dengan pengaturan populasi tanaman melalui pengaturan jarak tanamdan sistem tanam jajar legowo (Suhendrata, 2017).

Penggunaan varietas unggul baru padi dengan menerapkan sistem tanam jajar legowo diharapakan mampu meningkatkan produktivitas tanaman padi. Sistem tanam jajar legowo adalah pola bertanam yang berselang-seling antara dua atau lebih (biasanya dua atau empat) baris tanaman padi dan satu baris kosong. Prinsip teknologi sistem tanam jajar legowo adalah meningkatkan populasi pertanaman, menambah kelancaran sirkulasi udara di sekeliling tanaman pinggir serta orientasi pertanaman dalam pemanfaatan radiasi surya sehingga tanaman dapat berfotosintesis dengan baik sehingga dapat meningkatkan produktivitas padi hingga mencapai 10-15\%. (Abdulrachman dkk. 2013). Hasil beberapa penelitian menunjukkan terdapat variasi respon hasil beberapa varietas padi sawah irigasi terhadap jarak tanam yang menunjukkan hasil berbeda. Varietas Inpari 14, 15, 18 dan 19 yang menggunakan sistem tanam jajar legowo menunjukkan hasil lebih tinggi dibandingan dengan sistem tegel biasa, sebaliknya pada varietas Inpari 4,8 , dan 13 memiliki hasil lebih tinggi dengan sistem tegel dibandingkan dengan sistem jajar legowo (Ikhwani dkk., 2013). Sistem tanam jajar legowo pada padi sawah secara umum bisa dilakukan dengan berbagai tipe yaitu : Legewo $(2: 1),(3: 1),(4: 1),(5: 1)$, dan $(6: 1)$. Hasil penelitian (Sari dkk., 2014 ; Suhendrata, 2017) menunjukkan tipe tanam jajar legowo 2:1 merupakan tipe tanam terbaik bagi pertumbuhan dan hasil padi sawah.
Tujuan penelitian adalah untuk mengetahui produktivitas Inpari 32 pada sistem jajar legowo 2:1 dengan perlakuan jarak tanam yang berbeda.

\section{METODA PENELITIAN}

\subsection{Tempat dan Waktu}

Pengkajian dilaksanakan pada lahan sawah KP Samboja, Desa Bukit Raya, Kecamatan Samboja Kabupaten Kutai Kartangera Kalimantan Timur pada bulan JuliOktober 2019.

\subsection{Bahan dan Alat}

Bahan-bahan yang digunakan dalam peneltian ini adalah varitas Inpari 32, pupuk NPK, pupuk Urea, Insektisda dan Fungisida. Sedangkan alat-alat yang digunakan antara lain alat tulis menulis, papan, bambu, tali, penggaris, timbangan, cangkul, sabit.

\subsection{Rancangan Penelitian}

Pengkajian terdiri atas 2 perlakuan jarak tanam sistem tanam jajar legowo 2:1, yaitu $20 \times 10 \times 40 \mathrm{~cm}$ dan $20 \times 10 \times 50 \mathrm{~cm}$, masing-masing perlakuan diulang 3 kali. Data yang dikumpulkan meliputi jumlah anakan produktif (batang), panjang malai $(\mathrm{cm})$, jumlah gabah isi (bulir), jumlah gabah hampa (bulir) dan hasil gabah hasil panen (GKP). Analisis data untuk membandingkan antara 2 perlakuan jarak tanam jajar legowo 2:1 dengan uji t berpasangan dengan menggunakan software Co. Stat 6.1.

\subsection{Pelaksanaan Penelitian Persiapan Benih}

Sebelum ditanam, benih direndam selama 24 jam dengan air (Atonik + Cruiser), kemudian di tiriskan kemudian diperam selama 24 jam.

\section{Persemaian}


Benih ditaburkan pada petak persemaian yang kondisi airnya macak-macak. Sebelum benih ditaburkan petak persemaian diberikan Ponska dengan dosis $5 \mathrm{~g} / \mathrm{m}^{2}$ dengan cara disebar, kemudian benih-benih tersebut disebar merata,pemupukan menggunakan Urea dengan dosis $5 \mathrm{~g} / \mathrm{m}^{2}$.

\section{Persiapan Tanam}

Sebelum penanaman, tanah diolah terlebih dahulu dengan menggunakan traktor untuk membalik tanah dan meratakannya.

\section{Penanaman}

Bibit hasil persemaian dipindah (transplanting) setelah berumur 18 hari setelah semai, kemudian ditanam dua bibit/lubang.

\section{Pemupukan}

Pemupukan dilakukan sebanyak 2 kali dengan cara disebar. Pemberian pupuk dasar menggunakan pupuk NPK Ponska dan urea dengan dosis $300 \mathrm{~kg} / \mathrm{ha}$ dan 150 $\mathrm{kg} / \mathrm{ha}$, diberikan pada umur 7 hari setelah tanam. Kemudian dilanjutkan dengan pemupukan susulan pertama yang dilakukan 30 hari setelah tanam (HST) menggunakan pupuk Urea dosis 150 $\mathrm{kg} / \mathrm{ha}$ setelah penyiangan pertama.

\section{Pengairan}

Pengelolaan air pada awal tanam tinggi air dipertahankan $\pm 3 \mathrm{~cm}$ agar bibit tidak terendam. Setelah bibit tumbuh dan muncul anakan (10-12 HST) sampai masa pengisian bulir, tinggi air diatur hingga 10-15 $\mathrm{cm}$. Pada saat 10 hari sebelum panen (HSP) petak dikeringkan

\section{Penyulaman}

Penyulaman dilakukan untuk menggantikan tanaman yang mati, tidak sehat dan tidak tumbuh. Tanaman yang digunakan adalah tanaman cadangan dari sisa persemaian.Penyulaman dilakukan pada saat tanaman berumur satu minggu setelah tanam.

\section{Penyiangan}

Penyiangan dilakukan ketika terdapat gulma. Penyiangan dilakukan dengan cara mencabut gulma yang berada di sekitar tanaman.

\section{Pengendalian Hama dan Penyakit}

Pengendalian hama dan penyakit dilakukan sesuai dengan kaidah pengendalian hama terpadu.

\section{Panen}

Panen dilakukan setelah tanaman memiliki bulir padi $80 \%$ telah menguning, tangkai padi merunduk karena bulir padi keras dan daun berwarna kuning.

Tabel 1. Teknologi yang diterapkan pada budidaya tanaman padi irigasi

\begin{tabular}{llcc}
\hline No. & Uraian & \multicolumn{2}{c}{ PerlakuanJarak Tanam } \\
\cline { 3 - 4 } & & Kelas BS & J2 \\
2 & Benih & Inpari 32 & Inpari 32 \\
3 & Persemaian & Sistem Dapog & Sistem Dapog \\
4 & Pengolahan Lahan & Sempurna & Sempurna \\
5 & Umur Bibit & $18 \mathrm{HST}$ & $18 \mathrm{HST}$ \\
6 & Jarak Tanam & $20 x 10 x 40 \mathrm{~cm}$ & $20 x 10 \times 50 \mathrm{~cm}$ \\
7 & Pupuk & & \\
& Urea & $200 \mathrm{~kg} / \mathrm{ha}$ & $\mathrm{kg} / \mathrm{ha}$ \\
& NPK & $300 \mathrm{~kg} / \mathrm{ha}$ & $300 \mathrm{~kg} / \mathrm{ha}$ \\
8 & Penyemprotan & Sprayer elektrik & Sprayer elektrik \\
9 & Penyiangan & Gasrok dan Manual & Gasrok dan Manual \\
10 & Perontokan Padi & Power Thresher & Power Thresher \\
\hline
\end{tabular}




\section{HASIL PENELITIAN DAN PEMBAHASAN}

Karakter tinggi tanaman pada perlakuan JI dan J2 menunjukkan adanya perbedaan yang nyata. Rerata tinggi tanaman perlakuan J1 yaitu 94, 2 sedangkan perlakuan J2 yaitu 108,7. Sejalan dengan hasil penelitian (Danuri dkk.,2017) meyebutkan pengaruh jarak tanam berpengaruh nyata terhadap karakter tinggi tanaman. Berdasarkan penggolongan tinggi tanaman padi, perlakuan $\mathrm{J} 1$ dan $\mathrm{J} 2$ tergolong rendah yaitu kurang dari $110 \mathrm{~cm}$. Tinggi tanaman berkorelasi positif dengan tingkat kerebahan, sehingga varietas dengan batang pendek berpeluang akan lebih tahan terhadap kerebahan.

Kapasitas anakan merupakan salah satu sifat utama yang penting pada varietas-varietas unggul. Jumlah anakan produktif per rumpun pada perlakuan jarak tanam J1 $(20 \times 10 \times 40 \mathrm{~cm})$ dengan $\mathrm{J} 2(25 \times 12.5 \times 50 \mathrm{~cm})$ menunjukkan adanya kecenderungan semakin lebar jarak tanam jumlah anakan akan semakin meningkat pula dan berbeda nyata (Tabel
2). Rerata jumlah anakan produktif JI yaitu 19,1 batang, sedangkan jumlah anakan produktif $\mathrm{J} 2$ yaitu $25,4 \mathrm{~cm}$. Hasil penelitian (Suhendrata, 2017; Danuri, 2017) menunjukkan bahwa jarak tanam berpengaruh nyata terhadap jumlah anakan produktif. Menurut Yoshida (1981) selain cahaya dan pasokan hara, jarak tanam merupakan faktor yang mempengaruhi jumlah anakan. Pasokan hara Nitrogen dan Fosfat juga mempengaruhi jumlah anakan. Kadar nitrogen tanaman di atas 3,5\% sudah cukup untuk merangsang pembentukan anakan, sedangkan pada kadar 2,5\% pembentukan anakan akan terhenti, dan bila kadar $\mathrm{N}$ tanaman kurang dari 1,5\% anakan-anak akan mati. Selain itu fosfat juga mempengaruhi pembentukan anakan. Bila kadar fosfat batang utama kurang dari $0,25 \%$, maka pembentukan anakan akan terhenti (Makarim dan Suhartatik, 2009). Bila dikategorikan maka perlakuan J1 memiliki jumlah anakan produktif tergolong sedang (11-20 batang), sedangkan pada perlakuan $\mathrm{J} 2$ tergolong banyak yaitu lebih besar dari 20 batang (IRRI, 2003).

Tabel 2. Rerata karakter komponen hasil yang diamatipada varietas Inpari 32

\begin{tabular}{lccc}
\hline Karakter & \multicolumn{2}{c}{ Perlakuan } & \multirow{2}{*}{ Notasi* } \\
\cline { 2 - 3 } & $\mathrm{J} 1$ & $\mathrm{~J} 2$ & \\
\hline \hline Tinggi Tanaman (cm) & 94,2 & 108,7 & Nyata \\
Jumlah Anakan Produktif (batang) & 18,7 & 23,9 & Nyata \\
Panjang Malai (cm) & 19,9 & 23 & Nyata \\
Jumlah Gabah Isi permalai (bulir) & 88,9 & 104,9 & Nyata \\
Hasil Gabah (ton/ha GKP) & 6,3 & 7,5 & Nyata \\
\hline
\end{tabular}

Ket : J1= Jarak Tanam $20 \times 10 \times 40 \mathrm{~cm} ; \mathrm{J} 2=$ Jarak Tanam $25 \times 12.5 \times 50 \mathrm{~cm}$; * uji t dengan $\alpha=5 \%$.

Panjang malai merupakan salah satu komponen hasil yang mendukung produktivitas (Kartina dkk., 2016). Panjang malai pada kedua perlakuan menunjukkan adanya perbedan yang nyata, pada perlakuan J1 rerata panjang malainya yaitu $19,9 \mathrm{~cm}$, sedangkan pada perlakuan $\mathrm{J} 2$ panjang malai yiatu $23 \mathrm{~cm}$. Berdasarkan penggolongan panjang malai maka J1 termasuk dalam kotegori pendek dan J2 termasuk kategori sedang (IRRI, 2003).Pengaruh jarak tanam terhadap 
panjang malai belum banyak dilaporkan. Malai yang panjang dapat menghasilkan lebih banyak cabang dan bunga sehingga semakin besar peluang jumlah gabah terbentuk, namun malai yang terlalu panjang juga dapat menyebabkan waktu masak antara bulir awal dan bulir yang akhir muncul terlalu jauh sehingga banyak menghasilkan gabah hampa.

Menurut (Subekti, 2011) jumlah gabah berisi permalai memiliki korelasi fenotipik maupun genotipik yang searah dengan serapan P. Jumlah gabah berisi pada kedua perlakuan menunjukkan adanya perbedan yang nyata. Perlakuan J2 memiliki rerata jumlah gabah isi per malai yang lebih tinggi dibandingkan dengan J1. Jarak tanam yang lebar memungkinkan memberikan keleluasaan pertumbuhan padi, sehingga sinar matahari maksimal diterima oleh daun untuk berfotosintesis untuk memproduksi gabah.

Hasil pada tanaman padi dilaporkan sebagai gabah (rough rice) pada kadar air 14\% (Yoshida, 1981). Jarak tanam pada tanaman padi akan berpengaruh terhadap hasil, adanya perbedaan jarak tanam yang berbeda akan menghasilkan jumlah populasi yang berbeda. Produktivitas hasil ubinan berdasaran jarak tanam menunjukkan bahwa produktivitas J2 (25 x $12,5 \times 50 \mathrm{~cm}$ ) yaitu 7,5 ton/ha GKP lebih tinggi dibandingkan $\mathrm{J} 1(20 \times 10 \times$ $40 \mathrm{~cm}$ ) yaitu 6,3 ton/ha GKP dan berbeda nyata. Tingginya hasil perlakuan J2 didukung pula oleh komponen hasil berupa jumah anakan produktif, panjang malai serta jumlah gabah berisi permalainya. Artinya selain lingkungan berupa pengaturan jarak tanam, hasil suatu tanaman ditentukan oleh faktor komponen hasil suatu tanaman tersebut. Menurut (Endrizal dan Bobihoe, 2007) bahwa sifat komponen hasil antara satu dengan yang lainnya memiliki hubungan erat. Ketidak seimbangan diantara komponen hasil tersebut akan sangat mempengaruhi potensi hasil yang diperoleh. Selanjutnya Muliarta dkk., (2012) menyatakan hasil gabah per hektar sangat dipengaruhi oleh beberapa komponen hasil diantaranya adalah jumlah anakan produktif dan jumlah gabah isi per malai.

\section{KESIMPULAN}

Perlakuan Jarak Tanam (25 x 12,5 x $50 \mathrm{~cm}$ ) pada karekter tinggi tanaman, jumlah anakan produktif, panjang malai, jumlah gabah berisi per malai serta hasil memiliki nilai rerata yang lebih tinggi dan nyata dibandingkan denga perlakuan jarak tanam $(20 \times 10 \times 40 \mathrm{~cm})$.

\section{DAFTAR PUSTAKA}

Abdulrachman, S., Mejaya, M.J., Agustiani,N., Guanawan, I., Sasmita, P., dan Guswara. (2013). Sistem Tanam Legowo. Badang Penelitian dan Pegembangan Pertanian.

Danuri, Radian, dan Nurjani. (2017). Pengaruh Jarak Tanam dan Jumlah Bibit terhadap Pertumbuhan dan Hasil Padi Di Lahan Sawah Tadah Hujan. Agrovigor. 10 (2): 121-127.

Endrizal dan Bobihoe J. (2007). Pengujian Beberapa Galur Unggulan Padi Dataran Tinggi di Kabupaten Kerinci Provinsi Jambi. Balai Pengkajian Teknologi Pertanian. Jambi.

Hamdani, K.K., dan Murtiani, S. (2014). Aplikasi sistem tanam jajar legowo untuk meningkatkan Produktivitas padi sawah. Agros. 16 (92) : 285-291.

Ikhwani, Pratiwi, G.R., Paturrohman, E., dan Makarim. A.K. (2013). Peningkatan Produktivitas Padi 
Melalui Penerapan Jarak Tanam Jajar Legowo. Iptek Tanaman Pangan. 8 (2): 72-79.

IRRI. (2003). Standard Evaluation System for Rice (SES). International Rice Research Institute. Los Banos

Kartika, N., Wibowo, B.P., dan Widyastuti, Y. (2016). Korelasi dan Sidik Lintas Karakter Agronomi Padi Hibrida. JIPI. 21 (2): 76-83.

Makarim.,K.A dan Suhartatik.,E dan. (2009). Morfologi dan Fisiologi Tanaman Padi. Balai Besar Penelitian Tanaman padi. 295-330.

Muliarta, Sudantha I. M., Bambang B. S. (2012). Daya Hasil dan Penampilan Fenotifik Karakter Kuantitatif Galur-Galur F2BC4 Padi Gogo Beras Merah. Prosiding InSINas.

Sari, D.N., Sumardi, dan Suprijono. (2014). Pengujian Berbagai Tipe Tanam Jajar Legowo terhadap Hasil Padi Sawah. Akta Agrosia. 17 (2): 115-124.

Sembiring, H. (2008). Kebijakan penelitian dan rangkuman hasil penelitian BB Padi dalam mendukung peningkatan produksi beras nasional. Dalam: Prosiding Seminar Apresiasi Hasil Penelitian Padi Menunjang P2BN. Balai Besar Penelitian Tanaman Padi. Hal 3959.
Subekti, P. (2011). Adaptasi Lima Puluh Genotipe Padi Gogo pada Tiga Lingkungan Kemasaman Tanah Ultisol. Widyariset. 14 (2) : 286294.

Suhendrata, T. (2017). Pengaruh Jarak Tanam Pada Sistem Tanam Jajar Legowo Terhadap Pertumbuhan, Produktivitas Dan Pendapatan Petani Padi Sawah Di Kabupaten Sragen Jawa Tengah. SEPA. 13 (2) : 118-194.

Yoshida S. (1981). Dasar-Dasar Pengetahuan Tentang Tanaman Padi. (Terjemahan dari "Fundamental Rice"). IRRI. Los Banos, Laguna, Philippines. 